\title{
References:
}

1. Grudevich, T. (2019). Muzeina tematyka u lystuvanni M.I. Sikorskoho v 70-kh rokakh XX na poch. XXI st. (za materialamy fondovoi kolektsii Natsionalnoho istoryko-etnohrafichnoho zapovidnyka «Pereiaslav») [Museum subject in correspondence Sikorsky in the 70's of the XX at the beginning. XXI century. (based on materials of the Pereyaslav Research Institute stock collection] Journal of Ukrainian History / Edited by Doctor of Historical Sciences, Professor A.P. Kotsur. Kyiv, vol. 39, pp. 124-129.

2. Fondy natsionalnoho istoryko-etnohrafichnoho zapovidnyka «Pereiaslav». Hrupa TZ (tymchasove zberihannia) [Funds of «Pereyaslav» National Historical and Ethnographic Reserve. TK Group (temporary storage)].

\section{FORMATION OF THE PEREYASLAVSKY SCANSEN: IDEA COMMUNICATION AND PRACTICE IN INTERNATIONAL SPACE}

\section{Elena Zham ${ }^{1}$}

DOI: https://doi.org/10.30525/978-9934-588-11-2_33

Monumental and museum work in Ukraine in 1960-1970's of XX century. characterized by a wave of mass interest in Ukrainian culture and the spread of the progressive idea of creating ethnographic museums of a new type - open-air museums, commonly called scans.

The first such museum in Ukraine was the Museum of Folk Architecture and Life in the Middle Dnieper region in Pereyaslav-Khmelnitsky, Kyiv region, which is one of the richest treasures of original folk architecture and life of the inhabitants of the Dnieper villages of the 19th - beginning of the 20 th. The museum is a part of National historical and ethnographic reserve «Pereyaslav».

It is one of the largest ethnographic museums in the country. 185 objects are exhibited in it 124 of which are architectural monuments of the XVII-XX century of local and national importance. According to the number of monuments among the post-Soviet countries, it is second only to the National Museum of Folk Architecture and Life of Ukraine in the village of Pyrogovo near Kiev (275 sites) and the Lithuanian Museum of National Life in Rumshishkes (189 sites).

An ancient village occupying an area of 24.2 hectares is, situated in a picturesque area on the outskirts of the city on a low hill, which is surrounded by the valleys of the rivers Popivka and Trubezh. It offers a magnificent view of the city, a wide and beautiful panorama of the Dnieper cliffs and floodplain meadows.

The museum presents a wide variety of peasant architecture (monuments of residential and economic, public and sacral purpose), a collection of tools, household items, articles of craftsmen.

Formation of the museum began in 1958 with the creation of an ethnographic exhibition on the territory of St. Michael's Church. A fragment of the interior of the

\footnotetext{
${ }^{1}$ National Historical and Ethnographic Reserve «Pereyaslav», Ukraine
} 
Ukrainian peasant's house was recreated in the refectory room, and the first architectural monuments (pantry, windmill) were installed in the yard. A large collection of agricultural implements, drawn vehicles, potter's and tanner's workshops complemented the exhibition. At this time the idea of creating a fully fledyed open-air ethnographic museum arose.

The museum was opened in 1964 and was dedicated to the 150th anniversary of TG. Shevchenko. In honor of the memory of the poet's stay in Pereyaslav region, it was decided to create a park with the area of 5 hectares and an ethnographic museum.

Unlike other similar museums, which have a large territory, the Pereyaslav scansen is quite compact, everything in it is, placed logically in chronological order. The architectural and ethnographic complex includes 12 separate thematic museums that form an interconnected complex with the scansen. They look organic because they are housed in authentic buildings.

In the process of formation of a scansen in Pereyaslav-Khmelnitsky, Kyiv region (Ukraine), its founders (M. Sikorsky, M. Zham, E. Ishchenko) collaborated with Ukrainian, All-Union and foreign institutions, prominent socio-cultural, public and scientific figures that had a positive influence on the establishment of scientific positions, the implementation of the concept in practice.

The Deputy Chairman of the Council of Ministers did particulary much for the museum - he helded to get land. The prominent figures of science and culture of Ukraine were involved in this case: architects V. Zabolotny, Y. Aseev, S. Vergovsky, poet and academician M. Rylsky, ethnographers I. Gonchar and K. Guslysty, judge of Shevchenko E. Kyryliuk, art historian V. Danyleiko, Russian architect and restorer R. Opolnikov.

In the summer of 1960, M. Zham visited the State Museum of Ethnography of the Peoples of the USSR (Leningrad, Russia, Order No. 24 of July 31, 1960). The exposition of this museum is dedicated to the everyday culture of the peoples of Russia and neighboring countries (Ukraine, Belarus, Baltic States, Central Asia, Transcaucasia). In the halls of the Ethnographic Museum materials that tell about the occupation of the population, construction and arrangement of housing, features of clothing, holidays and ceremonies are presented. Here household items, tools, ritual attributes are exhibited. M. Zham was tasked with working out materials related to the Ukrainian peasant life and establishing cooperation with the ethnographic department of Belarus, Ukraine, Moldova.

In 1962-1964, scientists of the Pereyaslav-Khmelnitsky Historical Museum collaborated with scientists of the Institute of Arts, Folklore and Ethnography of the Academy of Sciences of the Ukrainian SSR on the compilation of the «Ukrainian Historical and Ethnographic Atlas». Workers of the State Museum of History in Kyiv provided considerable assistance, in particular, they provided some of their materials for display.

Close cooperation has combined the Pereyaslav museums with the Museum of Ethnography and Artistic Craft of the Academy of Sciences of the Ukrainian SSR in Lviv, especially with D. Figol and K. Mateiko. The family archives of the author of this article have preserved the letters addressed to these scholars by M. Zham. Lviv's 
colleagues introduced M. Zham to a well-known Czech ethnographer, director of the Moravian Museum in Brno, Dr. L. Kuntz. Moravian Museum is one of the oldest and largest museums in the Czech Republic. In 1963 L. Kuntz began the work on the preparation of a scientific collection on the subject of the creation of open-air museums in the world. He learned from his Lviv colleagues about the scans in Pereyaslav-Khmelnitsky, and he asked the Pereyaslav museums to offer an article about the museum. It was published in 1966 in the journal MUSEUM, with the support of UNESCO [1, p. 187-188].

The creation of the first Ukrainian scansen became known in the scientific circles of the neighboring republics and Europe. At the beginning of 1961 Pereyaslav museums workers were invited to participate in the work of the All-Union meeting of ethnographers, which was held on June 5-17, 1961 on the basis of Latvian Etnogrāfiskais brīvdabas muzejs. It is one of the largest scans in Europe, founded in 1924. It is located on the shore of Lake Jugl in the outskirts of Riga. On the territory of 84 hectares there are 118 residential, commercial and public buildings, built in the XVII-XIX centuries in different historical regions of Latvia. Pereyaslav was represented at this meeting by the head of the ethnographic department M. Zham. He acquainted the audience with the history of the creation of the first ethnographic exposition on the basis of the St. Michael's Church in Pereyaslav-Khmelnitsky, noted that the possibilities of closed premises of the church and a small courtyard for displaying monuments of folk architecture and creating interiors are extremely limited and in connection with this he outlined the immediate plans - the creation of a scansen in the outskirts of the city.

In April 1966, a working group was formed at the Bokrijk Museum (Hake, Belgium), composed of the heads of open-air museums under the official name of the Working Society of European Open-Air Museums. A. Tsipelius was commissioned to prepare a guide to the scans of the world. From the director of the Moravian Museum (Brno, Czechoslovakia), Dr. L. Kunz A. Tsipelius, became aware of the existence of an open-air museum in Ukraine, in Pereyaslav-Khmelnitsky. Therefore, he asked M. Zham to send the materials to the directory, in particular, to fill out a form about the museum.

In September 1966, the directors of the Scansecn museums gathered at an international symposium on topical issues of open-air museums in Romania. Pereyaslav museums workers couldn't attend the international symposium in Romania. Only in 1984 M. Zham visited the scansen in Bucharest, and on September 23, 1970, the Honored Artist of Ukraine, the winner of the Shevchenko Prize, G. Sinitsa, presented the museum a book by Gerge Foksch, «Bucharest Museum Village» (Bucharest, 1958), in which there were a lot of posts and thematic clippings from newspapers and magazines about this museum.

The second international symposium on topical problems of the Scansen was held on 23-26 September 1967 in Switzerland, in Brintz. On July 24-28, 1968, a regular conference was planned in the German town of Cologne. M. Sikorsky and M. Zham were invited to attend this meeting and the extended ICOM Congress. To obtain permission to travel abroad, M. Sikorski addressed the Ministry of Culture of the 
USSR, stating that it would be useful to get acquainted with the structure and principles of organizing the oldest open-air museums in Europe, to find out how important European museums are, and they have not resolved problems yet. However, the trip failed.

In 1962, an acquaintance handed M. Zam a copy of the Polish newspaper «Standar Molody» for November 27 with the note «Open Air Museum». It mentioned plans to open several open-air museums in Poland in the fields of architecture, archeology, ethnography near Warsaw and in Chersk. In October 1966, M. Sikorski managed to visit Poland and evaluate the achievements of his Polish colleagues in the creation of the Scans. In December 1970, with a view to sharing his experience, M. Sikorsky visited Czechoslovakia, in November 1976 - Sri Lanka and India. The Pereyaslav scholars followed closely the creation of the Lithuanian Museum of National Life in Rumshishkes (founded in 1966), which reflects the traditional rural life of the Lithuanians of the 19th and early 20th centuries of four historical regions of Lithuania. M. Zham planned to visit it in 1972, but failed.

In the end of the $60 \mathrm{~s}$ of the XX century, in Pereyaslavsk scansen the first organizational works were done, the full exposition was formed. At that time, his project had no precedents in Ukraine, so the path to the realization of this idea was difficult and long. Foreign experience in creating open-air ethnographic exhibitions was especially useful, as the museum practice of Ukraine still lacked theoretical knowledge, polished methodology, clear principles of museum studies, international standards, and good work experience. The approaches of Pereyaslav museums to this new, methodically and practically not developed business, were creative and original. The experience of its founders was useful for creating other museums of folk architecture and life in Ukraine.

\section{References:}

1. Sikorskij, M. I. (1966). The open-air Ethnographic Museum of Pereyaslav-Khmelnitsky. MUSEUM, vol. XIX, no 3, pp. 187-188.

\section{AT THE ORIGINS OF GERMAN CLASSICAL ARCHEOLOGY: ADOLF FURTWÄNGLER}

\section{Oleksii Prysiazhniuk $^{1}$}

DOI: https://doi.org/10.30525/978-9934-588-11-2_34

Possessing versatile and deep knowledge in his field, distinguished by amazing energy and productivity, conducting all his research on the basis of a broad historical horizons, Adolf Furtwängler (1853-1907) for 33 years of his scientific, in the full sense of the word, work, was able to enrich classical archeology with a number of

\footnotetext{
${ }^{1}$ South Ukrainian National Pedagogical University named after K.D. Ushynsky, Ukraine 